\title{
Melatonin: highlighting its use as a potential treatment for SARS-CoV-2 infection
}

\author{
Russel J. Reiter ${ }^{1}\left[\right.$. Ramaswamy Sharma $\cdot$ Fedor Simko ${ }^{2} \cdot$ Alberto Dominguez-Rodriguez $^{3} \cdot$ Jan Tesarik $^{4}$. \\ Richard L. Neel ${ }^{5} \cdot$ Andrzej T. Slominski $^{6,7} \cdot$ Konrad Kleszczynski $^{8} \cdot$ Verna M. Martin-Gimenez ${ }^{9} \cdot$ Walter Manucha ${ }^{9,10}$. \\ Daniel P. Cardinali ${ }^{11}$
}

Received: 19 October 2021 / Revised: 29 November 2021 / Accepted: 16 December 2021 / Published online: 20 February 2022

(c) The Author(s) 2022

\begin{abstract}
Numerous pharmaceutical drugs have been repurposed for use as treatments for COVID-19 disease. These drugs have not consistently demonstrated high efficacy in preventing or treating this serious condition and all have side effects to differing degrees. We encourage the continued consideration of the use of the antioxidant and anti-inflammatory agent, melatonin, as a countermeasure to a SARS-CoV-2 infection. More than 140 scientific publications have identified melatonin as a likely useful agent to treat this disease. Moreover, the publications cited provide the rationale for the use of melatonin as a prophylactic agent against this condition. Melatonin has pan-antiviral effects and it diminishes the severity of viral infections and reduces the death of animals infected with numerous different viruses, including three different coronaviruses. Network analyses, which compared drugs used to treat SARS-CoV-2 in humans, also predicted that melatonin would be the most effective agent for preventing/treating COVID-19. Finally, when seriously infected COVID-19 patients were treated with melatonin, either alone or in combination with other medications, these treatments reduced the severity of infection, lowered the death rate, and shortened the duration of hospitalization. Melatonin's ability to arrest SARS-CoV-2 infections may reduce health care exhaustion by limiting the need for hospitalization. Importantly, melatonin has a high safety profile over a wide range of doses and lacks significant toxicity. Some molecular processes by which melatonin resists a SARS-CoV-2 infection are summarized. The authors believe that all available, potentially beneficial drugs, including melatonin, that lack toxicity should be used in pandemics such as that caused by SARS-CoV-2.
\end{abstract}

Keywords Cytokine storm · COVID-19 · Viral infection · Coronavirus · Sepsis · Hypoxia-inducible factor 1- $\alpha$. Phospholipase A2

Russel J. Reiter

reiter@uthscsa.edu

Ramaswamy Sharma

sharmar3@uthscsa.edu

1 Department of Cell Systems and Anatomy, UT Health San Antonio, Long School of Medicine, San Antonio, TX, USA

2 Institute of Pathophysiology, Faculty of Medicine, Comenius University, Bratislava, Slovak Republic

3 Department of Cardiology, Hospital Universitario de Canarias, Santa Cruz de Tenerife, Spain

4 MARGen Clinic, 18006 Granada, Spain

5 CEO, Alcasian Care Enterprises, Castroville, TX, USA

6 Department of Dermatology, University of Alabama at Birmingham, Birmingham, AL, USA
7 Pathology and Laboratory Medicine Service, VA Medical Center, Birmingham, AL, USA

8 Department of Dermatology, University of Münster, Münster, Germany

$9 \quad$ Instituto de Investigaciones en Ciencias Químicas, Facultad de Cs. Químicas Y Tecnológicas, Universidad Católica de Cuyo, San Juan, Argentina

10 Área de Farmacología, Departamento de Patología, Facultad de Ciencias Médicas, Universidad Nacional de Cuyo, Mendoza, Argentina

11 Faculty of Medical Sciences, Pontificia Universidad Católica Argentina, Buenos Aires, Argentina 


\section{Introduction}

Since the classification of SARS-CoV-2 infection as a pandemic, in excess of 140 publications have urged consideration of melatonin as a safe and potentially effective treatment for this worldwide disease [1-13]. The rationale for its use not only stems from its high safety profile [14-16] but also from its multiple beneficial actions in experimental and clinical studies related to the pandemic. This endogenously produced molecule is a broad-spectrum antiviral agent $[17,18]$ that has shown efficacy in reducing the severity of COVID19. Yet, the idea of its use has not generated any desirable interest at the governmental or pharmaceutical level. Meanwhile, numerous potentially toxic and expensive repurposed drugs have been espoused or used as clinical treatments, e.g., colchicine [19], glucocorticoids [20], remdesivir [14, 21], and many others [22-25]. Although of significant value, even the currently available vaccines are not without occasional serious side effects [26-28]. Moreover, the efficacy of the vaccines has decreased as the virus has mutated [29, 30]. Already, there are several variants that have been identified and there will likely be others that may further reduce the effectiveness of the vaccines. Summarized in this report are some actions of melatonin that support its use in the prevention and/or treatment of SARS-CoV-2 infections.

The search terms used to identify the published literature related to melatonin and its potential association with COVID-19/SARS-CoV-2 are summarized in Table 1. The searches used PubMed.gov and were performed on November 21, 2021. Among these reports, publications related to the ability of melatonin to suppress inflammation and the cytokine storm associated with COVID-19 disease were

Table 1 Results (number of related publications) of the search terms using Pubmed.gov which relate to COVID-19 and melatonin

\begin{tabular}{ll}
\hline Search terms & $\begin{array}{l}\text { Number of } \\
\text { publica- } \\
\text { tions }\end{array}$ \\
\hline COVID-19, melatonin & 143 \\
COVID-19, melatonin, inflammation & 47 \\
COVID-19, melatonin, cytokine storm & 30 \\
COVID-19, melatonin, ARDS* & 12 \\
COVID-19, melatonin, sepsis & 8 \\
COVID-19, melatonin, anosmia, ageusia & 1 \\
COVID-19, melatonin, aging & 10 \\
COVID-19, melatonin, human & 107 \\
COVID-19, melatonin, treatment & 97 \\
COVID-19, melatonin, mechanisms & 25
\end{tabular}

When SARS-CoV-2 was used in lieu of COVID-19, similar results were obtained. Searches were conducted on November 21, 2021

*ARDS Acute Respiratory Distress Syndrome most frequent. Melatonin use as a treatment for humans infected with SARS-CoV-2 also was a common consideration. A summary of the outcomes/endpoints of the studies/ clinical trials in which melatonin was used as a treatment or in which network analysis suggested the high likelihood of melatonin being an effective treatment for COVID-19 is discussed in the appropriate section below (See Effective Dose, Timing of Administration, Limitations, and Future Studies). The already-published data confirming the efficacy of melatonin in reducing the severity of human COVID-19 infection are summarized in tabulator form later in this report.

\section{Melatonin and sepsis}

While SARS-CoV-2 infections are generally thought of as a pulmonary issue, the consequences of this infection transcend the respiratory system. Ultimately, this disease becomes systemic with the development of severe sepsis or septic shock leading to multiple organ failure which is the condition that commonly leads to death of SARS-CoV2 -infected patients. Sepsis can occur as a consequence of a viral, bacterial, or fungal infection and, from a pathophysiological perspective, the damage to multiple organs leading to their failure and death of the patient has the same cause, i.e., the cytokine storm and hyperinflammation with extensive oxidative damage [17,31-33]. Due to is potent antioxidant and anti-inflammatory effects, melatonin has frequently been proposed for use to overcome the cytokine storm in virus-related infections $[34,35]$, including that caused by SARS-CoV-2 [36-38]) (Fig. 1).

In bacteria-related sepsis as well, melatonin is an effective prophylactic agent $[39,40]$. Importantly, melatonin prevented the death of premature newborn humans suffering from severe bacterial sepsis or septic shock [41] and melatonin has been suggested for use in individuals suffering from other serious bacterial infections, including necrotizing fasciitis [42, 43]. Recently, elevated levels of endogenous melatonin were found to correlate with the ability to resist brucellosis infection [44]. As observed by Snider et al. [45] in COVID-19-infected patients, excessive blood levels of sPLA2-IIA (a toxic phospholipase; see below) due to a bacterial infection are consequential in causing lung surfactant changes culminating in acute lung injury [46].

As with both gram-negative and gram-positive bacterial infections inducing sepsis, likewise fungal infestations, which are highly detrimental to lung physiology and difficult to successfully treat, promote similar organ and systemic pathologies, including sepsis and all of its ramifications [47, 48]. As highlighted by Root-Bernstein [12], the worst-case scenario for developing serious COVID-19 disease may involve combined infection of the lungs with the SARSCoV-2 virus and bacteria/fungi causing a synergistic action 
Fig. 1 The actions of melatonin that contribute to the ability of this ubiquitously distributed molecule in reducing the severity of a SARS-CoV-2 infection. HIF- $1 \alpha=$ hypoxia-inducible factor 1 alpha; $\mathrm{M} 1=$ pro-inflammatory macrophage; $\mathrm{M} 2=$ antiinflammatory macrophage; mtDNA = mitochondrial DNA; $\mathrm{NF}-\mathrm{\kappa B}=$ nuclear factor kappa $\mathrm{B} ; \mathrm{Nrf2}=$ transcription factor NF-E2 p45 transcription factor; PLA2 = phospholipase A2; RNS = reactive nitrogen species; ROS $=$ reactive oxygen species; SOD2 $=$ superoxide dismutase 2. Pointed arrow $=$ stimulation; blunt arrows $=$ inhibition

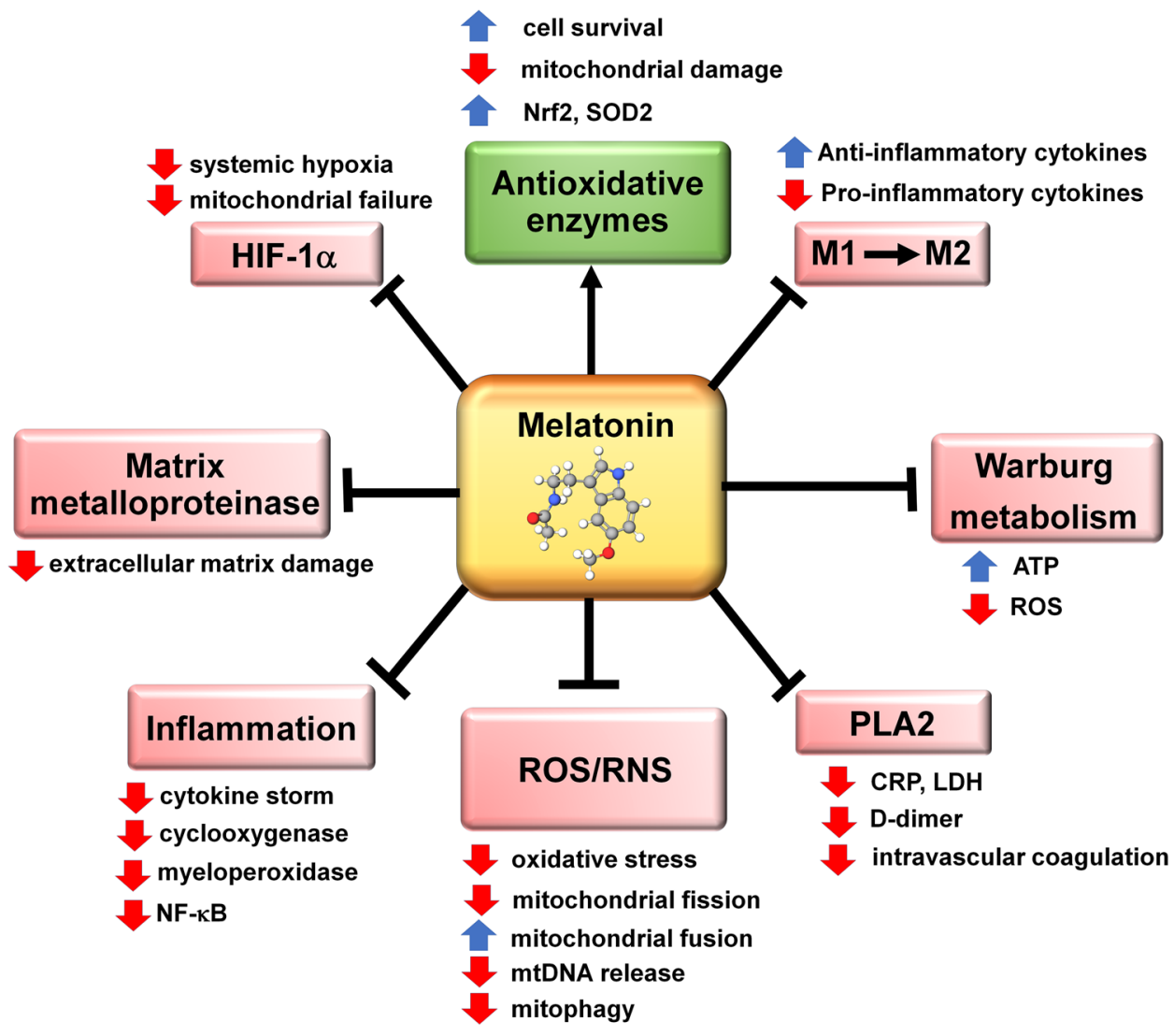

in stimulating an exaggerated cytokine storm and inducing acute respiratory distress syndrome (ARDS). Since melatonin is proposed to reduce the severity of viral, bacterial, and fungal infections, in the model proposed by Root-Bernstein [12], melatonin would seem to be a good treatment choice.

\section{Melatonin/HIF1a interactions}

A hallmark of septicemia, regardless of whether it is caused by a bacterium, virus, or a fungus, is the conversion of the metabolic phenotype of activated immune cells from mitochondrial oxidative phosphorylation to cytosolic glycolysis, i.e., Warburg-type metabolism [49-52]. Major contributors to the switch from mitochondrial glucose oxidation to the upregulation of pyruvate metabolism in the cytosol often are accompanied by stimulation of hypoxia-inducible factor- $1 \alpha$ (HIF-1 $\alpha$ ) and activation of NF-KB and other transcription factors which exaggerate inflammation [53-55]. In COVID19-infected patients, macrophages convert from M2 antiinflammatory to M1 pro-inflammatory cells which, along with other immune cells that exhibit a similar switch, contribute to the cytokine storm which leads to serious damage not only to the respiratory system but also in many other organs, thereby precipitating multiple organ failure $[44,56]$
(Fig. 1). Thus, melatonin may reduce the damage resulting from COVID-19-mediated septicemia by quelling HIF-1 $\alpha$, suppressing NF- $\mathrm{KB}$, inhibiting the inflammasome and converting pro-inflammatory M1 macrophages to anti-inflammatory M2 macrophages while also reversing Warburg-type metabolism [57, 58] (Fig. 1). The negative role of inducible factor- $1 \alpha(\mathrm{HIF}-1 \alpha)$ activation has been mentioned as a contributing factor to serious SARS-CoV-2 infections which involve the upregulation of the cytokine storm and the associated multi-organ failure [59-62].

HIF1- $\alpha$, also known as oxygen sensing transcription factor, is activated as a result of systemic hypoxia which occurs after the accumulation of edema and cellular debris in the respiratory alveoli which leads to poor $\mathrm{O} 2 / \mathrm{CO} 2$ exchange. Increased mortality is observed in patients with elevated HIF-1 $\alpha$ and an associated severe cytokine release [63]. Incremental changes in the level of HIF-1 $\alpha$ also help to explain why diabetics are more prone to severe SARSCoV-2 infections [64]; hyperglycemia leads to increased glycolysis in inflammatory monocytes and macrophages. This facilitates viral replication which contributes to elevated reactive oxygen species (ROS) generation which, in turn, stabilizes HIF1- $\alpha$. This supports glycolysis and exaggerates the cytokine storm in these individuals.

Melatonin is a well-recognized suppressor of HIF- $1 \alpha$ under a number of experimental conditions [65-67]. While 
the mechanism of that suppression is not specifically known [68], it may be the result of its direct inhibition of the cytosolic oxygen sensor or related to the potent antioxidant activity of the molecule which removes the agents that stabilize HIF-1 $\alpha$, i.e., ROS [69]. Thus, if the prediction of Codo et al. [64] is valid, which we feel it is, the inhibition of HIF- $1 \alpha$ would contribute to a reduction in lung damage and COVID-19 severity, then the use of melatonin as a treatment of SARS-CoV-2-infected patients would be further justified [70-72].

\section{Melatonin/PLA2 interactions}

The recent discovery of a correlation between circulating secreted phospholipase-A2 (Group IIA) (sPLA2-IIA) and the severity of COVID-19 disease [45] prompted the consideration of another potential mechanism by which melatonin may inhibit this viral infection. What Snider et al. [45] reported is that sPLA2-IIA levels and blood urea nitrogen (BUN) concentrations, indicative of renal damage, were strongly associated with the intensity of the infection and mortality of the infected patients. As a result of these correlations, the authors used the PLA-BUN index as a means to evaluate the likelihood of severe COVID-19 infections. Moreover, they proposed that suppression of sPLA2-IIA levels could be an important target to prevent or attenuate multiple organ failure, disseminated intravascular coagulation, and death of SARS-CoV-2-infected subjects.

Activated sPLA2-IIA is an inflammatory agent that is particularly destructive to cell biomembranes due to its ability to hydrolyzed fatty acids [73-75]. The membrane damage leads to the release of arachidonic acids and lysophospholipids; the arachidonic acids are then metabolized by cyclooxygenase to thromboxanes, prostacyclins, prostaglandins, etc. These eicosanoids promote inflammation and oxidative stress in multiple organs [76-78], which significantly contributes to vital organ dysfunctions (Fig. 1). The cell membranes that are damaged under systemic hyperinflammatory conditions include those of the mitochondria with energy failure being commonplace in these diseased situations [79]. By inhibiting cyclooxygenase, melatonin attenuates the hyperinflammatory response that accompanies a SARS-CoV-2 infection [80]. Hyperinflammation is often also accompanied by metabolic reprogramming, i.e., conversion of the inflamed cells to a usually pathological Warburg-type metabolism [81], a process that is reversed by melatonin $[82,83]$.

In addition to being elevated in individuals infected with SARS-CoV-2, high sPLA2-IIA levels have been measured in patients suffering from bacterial sepsis, a major killer of humans throughout the world, as well as from cardiac and hemorrhage shock [84]. The toxic actions of snake venoms also involve, along with an elevation of metalloprotease activities, increases in PLA2 [85]. Symptoms of snake venom toxicity include out-of-control inflammation and coagulopathy along with other complications and metabolic reprogramming of macrophages to the M1 hyperinflammatory phenotype [86]. In this context, the ability of melatonin to mitigate the toxicity of snake venoms has been documented [87, 88]. Although neither of these studies specifically examined the actions of melatonin on PLA2 activity, they report that it did counteract the extensive oxidative damage and inflammation in animals that were injected with the venom of the Egyptian cobra (Naja haje) or that of the saw scaled viper (Echis carinatus). The other enzymes known to be upregulated as a result of a venomous bite are metalloproteinases which in other pathological situations are also inhibited by melatonin [89]. Additionally, melatonin counteracts the effects of the nematocyst toxin of the purple-striped jelly fish (Pelagia noctiluca) [90]. The composition of this toxin is not well characterized but includes neuropeptides, prostanoids, membrane pore forming toxins, etc.

The commonality among the symptoms of these different conditions as they relate to SPLA2-IIA may explain some of the beneficial actions of melatonin as observed in a variety of disease situations, especially when intensive inflammation, excessive oxidative stress, mitochondrial dysfunction, metabolic reprogramming, and so on are involved. These signs are all common in individuals infected with SARS-CoV-2, where melatonin is protective. Melatonin has an unusually diverse skill set for suppressing diseases that are associated with these changes. Melatonin is a confirmed potent anti-inflammatory agent and antioxidant in many experimental models and clinical situations [32, 91-94]. It has been widely suggested for use as an antidote to COVID-19 infections, a recommendation supported by studies in both animal and in human studies [95, 96]. Clinically, melatonin treatment reduces the severity of SARS-CoV-2 infections in terms of lowering the seriousness of symptoms, decreasing the need for hospitalization (which simultaneously helps control health care exhaustion), reducing the duration of hospital stay when this is necessary, eliminating the need for mechanical intubation, and lessening the death rate $[4,11]$. Even prior to the identification of the current COVID-19 pandemic, melatonin was shown effective in reducing oxidative damage and lowering the inflammatory burden in other viral diseases [97-101], including those caused by other coronaviruses [102], and it has been classified as a potential pan-antiviral agent, although it is not viricidal. 


\section{Effective dose, timing of administration, limitations, and future studies}

Applications have been made for 10 clinical trials; most of these are on-going and are summarized in tabular form in the comprehensive report of Ramos et al. [16]. In these trials, total melatonin doses ranging between $2 \mathrm{mg}$ daily and $500 \mathrm{mg}$ daily are proposed for use; these are either given orally once per day or equally divided in multiple doses over a 24 -h period. One study is designed to use intravenously infused melatonin. The adult patients selected for treatment range from newly diagnosed to critically ill subjects in intensive care units; the primary outcomes to be assessed vary widely among the trials. None of these studies have proposed the use of children, possibly because SARS-CoV-2 infections are less common in young individuals. As in adults, melatonin use and safety in children has been tested where high doses of melatonin have been proven safe [41].

The wide variety of melatonin doses proposed in these trials is much like the already-published reports on the use of melatonin to treat COVID-infected adults (Table 2). In these reports the amounts of melatonin given fall between 3 and $600 \mathrm{mg}$ daily. Whereas all the studies reported positive outcomes when melatonin was used, none observed any toxicity of melatonin, including at the highest doses employed. In the report of a network analysis of drugs potentially useful in treating COVID, melatonin was suggested as the one to have the greatest likelihood of controlling SARS-CoV-2 infections [11]. The dose of melatonin that may be effective would possibly vary according to the age of the infected patient, since in aged individuals melatonin levels are often greatly diminished [106, 107]. Indeed, the greater susceptibility of the elderly to a SARS$\mathrm{CoV}-2$ has been speculated to be a result of the reduction in endogenous melatonin production [108]. Likewise, body size may be a consideration regarding the amount of melatonin administered. As a general rule, perhaps $1 \mathrm{mg}$ per kg body weight may be a starting point. Due to the high safety profile of melatonin, subsequent trials should also include individuals over a wide age range, including children.

When melatonin is used as a sleep aid or for some other uses, it is typically taken just before bedtime. This also is consistent with the rise in the nighttime endogenous melatonin released from the pineal gland [109]. In extreme situations, such as serious illness as during a COVID-19 infection (Table 2), melatonin was sometimes given in divided doses throughout each 24-h period. The rationale for this is that the elevated free radical generation as well as the inflammatory response associated with this disease persists during both the light and dark period. To aid in the inhibition of these damaging responses, it may improve the clinical outcome if melatonin is used as a treatment of infected individuals during the day, when circulating melatonin levels are at their nadir $[109,110]$.

There are some limitations to the already-published studies. While the endpoints were generally objective in terms of their measurement, usually the studies were not blinded. Co-morbidities among the treated patients varied as did the other drugs that were used concurrently. Some of the studies included a small number of patients. At this point, there is no standardization of the optimal route of administration or

Table 2 Clinical studies/trials in which melatonin was tested as a treatment for SARS-CoV-2 infection

\begin{tabular}{|c|c|c|c|c|}
\hline Reference & Study type & Number of patients & Total dose of melatonin & Outcomes \\
\hline $\begin{array}{l}\text { Castillo et al } \\
\text { [95] }\end{array}$ & Retrospective case & 20 & Oral, 36-72 mg (4 doses) & $\begin{array}{l}\downarrow \text { Need for mechanical ventilation } \\
\downarrow \text { Duration of hospitalization } \\
\uparrow \text { Survival }\end{array}$ \\
\hline Farnoosh et al. [96] & Randomized double-blind & 44 & $9 \mathrm{mg}$ (3 doses) & $\begin{array}{l}\downarrow \text { Pulmonary symptoms } \\
\downarrow \text { CRP* } \\
\downarrow \text { Duration of hospitalization }\end{array}$ \\
\hline Hassan et al. [103] & Randomized prospective & 158 & $10 \mathrm{mg}$ & $\begin{array}{l}\downarrow \text { Sepsis } \\
\downarrow \text { Microvascular coagulation } \\
\downarrow \text { Mortality }\end{array}$ \\
\hline Mousavi et al. [104] & Randomized prospective & 96 & $3 \mathrm{mg}$ & $\begin{array}{l}\uparrow \text { Blood oxygen } \\
\uparrow \text { Sleep time }\end{array}$ \\
\hline Alizadeh et al. [105] & Randomized prospective & 31 & $6 \mathrm{mg}$ & $\begin{array}{l}\downarrow \text { COVID symptoms } \\
\downarrow \text { CRP }\end{array}$ \\
\hline Ramlall et al. [4] & Retrospective & 13,394 & Different doses & $\begin{array}{l}\downarrow \text { Need for intubation } \\
\uparrow \text { Outcome for those intubated }\end{array}$ \\
\hline
\end{tabular}

The studies varied widely in terms of melatonin dosage and endpoints measured. Each of the reports suggest melatonin has efficacy in improving the outcome of the infected patients. The readers are urged to consult the original publications for further details

${ }^{*} C R P$ C-reactive protein 
of the time of day that would yield the best results. The most effective or necessary dose is also not established. On the positive side, melatonin has essentially no toxicity and, as a result, no LD50 has been established despite attempts to do so. As much as $1000 \mathrm{mg}$ has been given to healthy humans every day for a month without any substantial negative effects [111]. Also, melatonin is safe when administered via multiple routes. A key observation in a couple of the clinical reports was the reduced mortality of the melatonin-treated subjects (Table 2). Considering the preliminary findings in humans and the very large experimental base of information that strongly supports its efficacy as a treatment of COVID19, well-designed, placebo-controlled, double-blinded studies are needed. Hopefully, the on-going approved clinical trials will resolve essential treatment issues. Meanwhile, steps to identify in greater detail the mechanisms by which melatonin resists this viral and other viral infections should continue.

\section{Concluding remarks}

Beyond melatonin's well-known antioxidant and antiinflammatory actions which have proven the efficacy of this molecule in the treatment of diseases/ conditions where excessive free radical-mediated oxidative damage and hyperinflammation are causative factors [112-116], the studies summarized herein also support its use as a possible treatment for COVID-19 disease. Melatonin has been proposed as a potential effective inhibitor of the destructive inflammatory consequences of a SARS-CoV-2 infection $[2,4,7,11]$, an idea supported by observed and predicted improvements in the outcome of patients with this disease $[95,96]$ (Table 2). Numerous inter-related factors conspire to enhance the cytokine storm and multiple organ failure associated with COVID-19 disease severity and mortality, including elevated sPLA2-IIA, development of pro-inflammatory M1 macrophages, activation of HIF-1 $\alpha$, conversion to Warburg-type metabolism of immune cells, damage to mitochondria, massive release of cytokines, oxidative stress, etc. [117-120] (Fig. 1); each of these actions have been shown to be counteracted by melatonin. A center piece of this series of processes may be the alterations in mitochondrial physiology and the shift of glucose oxidation to the cytosol. This change in glucose handling markedly alters the metabolism of the mitochondria, which is critical to limiting cellular dysfunction, resisting disease, and preventing organismal death. Indeed, there are numerous maladies that are specifically classified as mitochondria-related diseases [121-125] with this category, including viral infections, such as SARS-CoV-2 [126-129].

If melatonin is in fact a significant antidote to SARSCoV-2 infection, the development of a Warburg-type metabolism by hyperactive immune cells and other diseased cells [130], may be indirectly a major contributor to COVID19 disease. This is because when intracellular glucose metabolism is reprogrammed from the mitochondria into the cytosol, the mitochondria can no longer synthesize acetyl coenzyme A (acetyl-CoA). This has high importance, since acetyl-CoA is a required co-substrate for intramitochondrial melatonin production [131], which normally occurs in these organelles of healthy cells but likely not in the mitochondria of highly inflamed cells [129]. Thus, in the absence of local melatonin synthesis in infected cells, the loss of this locally produced potent endogenously generated anti-inflammatory and antioxidant agent, the mitochondria lose a major portion of their protection against reactive oxygen species, inflammatory cytokines, etc., leading to their dysfunction; this contributes to a weakening of the cells with an increased susceptibility to cellular destruction by SARS-CoV-2. This would help explain the published data documenting the ability of melatonin to resist virus-related diseases, including that related to several different coronaviruses [102]. The ability of melatonin to reverse the Warburg effect in pathological cells in humans was recently documented, presumably allowing the mitochondria also to synthesize melatonin [129, 130].

The failure of melatonin to attract attention as a potential treatment for COVID-19 is somewhat disappointing considering a number of scientific/medical papers that have recommended its use. This may relate to a number of factors, including the lack of promotion of its therapeutic use for this disease by any influential group. Numerous already-available pharmaceutical drugs have been repurposed for the potential treatment of COVID-19. Yet, no organization/agency has proposed the use of melatonin even though it is much less expensive (sometimes a 100-fold less costly than the proposed prescription medications), and based on the outcomes of recent published trials $[95,96]$, it has efficacy in treating this condition. After an analysis of 27 publications related to the ability of drugs to successfully treat COVID-19, the authors concluded that melatonin is at least twice as effective as remdesivir or tocilizumab in reducing the inflammatory markers of a coronavirus 2019 infection [132]. Both remdesivir (Veklury) and tocilizumab (Actemra) are FDA authorized for use to treat select COVID patients suffering with a severe infection; both drugs have notable side effects and are given intravenously [133, 134]. In contrast, melatonin has a high safety profile and can be taken orally or administered by any other route [16]. Since melatonin is non-patentable and is inexpensive, the incentive of the pharmaceutical industry to support its use is lost. Finally, pharmaceutical drugs are sometimes enthusiastically advanced by individuals who stand to gain financially [135].

Better means of treatment for COVID-19 and other diseases, especially when a medication is less expensive and 
the toxicity of the suggested drug is minimal. All reasonable treatment options should equally be considered, not only those that have the backing of the most influential medical/pharmaceutical personnel [136]. Some in the profession have considered the COVID-19 pandemic an opportunity that should be exploited for personal gain. This is not permissible in medicine. There are examples of bias and/or conflicts of interest when treatment options for COVID-19 are considered [137].

A major purpose of the current report is to urge "leveling of the playing field" such that all potential reasonable options be considered to fight any serious, rapidly spreading disease, not only the COVID-19 pandemic [138]. The World Health Organization made a similar claim in 2014 during the Ebola outbreak in western Africa. In grave crises, such as during an Ebola epidemic or the COVID-19 pandemic, it is ethical to take advantage of all possible available and safe treatments even if their efficacy may not be definitively established especially when the drug has no serious side effects. Indeed, considering a large number of deaths that continue to occur worldwide due to SARS-CoV-2 infections, it may be unethical not to take advantage of any potentially safe treatments, especially if the vaccines become less effective due to continued mutations of the virus. People who are vulnerable and may be infected with such diseases should not have to wait for the development of a new vaccine which often requires months to years, an interval during which death of many patients may be the outcome. Additionally, the currently available mRNA COVID-19 vaccines are not safe for everyone, in particular for those who may have multiple allergies, and many individuals refuse to be vaccinated [139-141]. Moreover, the vaccines are not universally protective since vaccinated individuals still die of SARS-CoV-2 infections. The use of melatonin would be especially advantageous because it can be orally self-administered, it is low in cost, and it lacks significant toxicity. This applies especially to impoverished regions of the world where the populace has fewer financial resources to devote to the treatment of this disease and where health care is not readily available. Additionally, although this paper considers melatonin as a sole treatment for SARS-CoV-2 infections, it has also been suggested as a co-treatment with vaccines to improve their efficacy [15, 142-144] and in combination with other drugs [132]; this latter suggestion would be especially applicable when the medications have different but complimentary mechanisms of action to those of melatonin. Finally, to avoid or to reduce the likelihood of pervasive viral infections (e.g., by the highly deadly zoonotic Nipah virus currently invading India or the Omicron variation of SARS-CoV-2)) in the future, the profession should be more proactive as opposed to being reactive.
Author contributions Before writing began, all co-authors discussed the publications related to this report. The final selection of papers to be covered in the report was done by RJR and RS. The initial draft of the paper was written by RJR and then reviewed by all co-authors. The suggestions of all co-authors were incorporated into the final version of the review by RJR. All co-authors read and approved the final version of the manuscript.

Funding The authors would like to acknowledge funding for this manuscript via Grant VEGA 1/0127/17 (Fedor Simko).

Data availability Not applicable.

\section{Declarations}

Conflict of interest The authors declare no conflicts of interest.

Ethical approval Not applicable.

Consent to participate Not applicable.

Consent for publication Not applicable.

Ethical approval Not applicable.

Open Access This article is licensed under a Creative Commons Attribution 4.0 International License, which permits use, sharing, adaptation, distribution and reproduction in any medium or format, as long as you give appropriate credit to the original author(s) and the source, provide a link to the Creative Commons licence, and indicate if changes were made. The images or other third party material in this article are included in the article's Creative Commons licence, unless indicated otherwise in a credit line to the material. If material is not included in the article's Creative Commons licence and your intended use is not permitted by statutory regulation or exceeds the permitted use, you will need to obtain permission directly from the copyright holder. To view a copy of this licence, visit http://creativecommons.org/licenses/by/4.0/.

\section{References}

1. Cardinali DP (2020) High doses of melatonin as a potential therapeutic tool for the neurologic sequels of covid-19 infection. Melatonin Res 3(3):311-317. https://doi.org/10.32794/mr11250064

2. Cardinali DP, Brown GM, Pandi-Perumal SR (2020) Can Melatonin Be a Potential "Silver Bullet" in Treating COVID-19 Patients? Diseases. https://doi.org/10.3390/diseases8040044

3. Martin Gimenez VM, Prado N, Diez E, Manucha W, Reiter RJ (2020) New proposal involving nanoformulated melatonin targeted to the mitochondria as a potential COVID-19 treatment. Nanomedicine (Lond) 15(29):2819-2821. https://doi.org/10. 2217/nnm-2020-0371

4. Ramlall V, Zucker J, Tatonetti N (2020) Melatonin is significantly associated with survival of intubated COVID-19 patients. medRxiv. https://doi.org/10.1101/2020.10.15.20213546

5. Tesarik J (2020) Melatonin attenuates growth factor receptor signaling required for SARS-CoV-2 replication. Melatonin Res 3(4):534-537. https://doi.org/10.32794/mr11250077

6. Tan D-X, Hardeland R (2020) Estimated doses of melatonin for treating deadly virus infections: focus on COVID-19. Melatonin Res 3(3):276-296. https://doi.org/10.32794/mr11250062 
7. Zhang R, Wang X, Ni L, Di X, Ma B, Niu S, Liu C, Reiter RJ (2020) COVID-19: Melatonin as a potential adjuvant treatment. Life Sci 250:117583. https://doi.org/10.1016/j.lfs.2020.117583

8. Camp OG, Bai D, Gonullu DC, Nayak N, Abu-Soud HM (2021) Melatonin interferes with COVID-19 at several distinct ROSrelated steps. J Inorg Biochem 223:111546. https://doi.org/10. 1016/j.jinorgbio.2021.111546

9. Cross KM, Landis DM, Sehgal L, Payne JD (2021) Melatonin for the early treatment of COVID-19: a narrative review of current evidence and possible efficacy. Endocr Pract 27(8):850-855. https://doi.org/10.1016/j.eprac.2021.06.001

10. Esmaeili Gouvarchin Ghaleh H, Hosseini A, Aghamollaei H, Fasihi-Ramandi M, Alishiri G, Saeedi-Boroujeni A, Hassanpour K, Mahmoudian-Sani MR, Farnoosh G (2021) NLRP3 inflammasome activation and oxidative stress status in the mild and moderate SARS-CoV-2 infected patients: impact of melatonin as a medicinal supplement. Z Naturforsch C J Biosci. https://doi. org/10.1515/znc-2021-0101

11. Zhou Y, Hou Y, Shen J, Mehra R, Kallianpur A, Culver DA, Gack MU, Farha S, Zein J, Comhair S, Fiocchi C, Stappenbeck T, Chan T, Eng C, Jung JU, Jehi L, Erzurum S, Cheng F (2020) A network medicine approach to investigation and populationbased validation of disease manifestations and drug repurposing for COVID-19. PLoS Biol 18(11):e3000970. https://doi.org/10. 1371/journal.pbio.3000970

12. Root-Bernstein R (2021) Innate Receptor Activation Patterns Involving TLR and NLR Synergisms in COVID-19, ALI/ARDS and Sepsis Cytokine Storms: A Review and Model Making Novel Predictions and Therapeutic Suggestions. Int J Mol Sci https:// doi.org/10.3390/ijms22042108

13. Simko F, Reiter RJ (2020) Is melatonin deficiency a unifying pathomechanism of high risk patients with COVID-19? Life Sci 256:117902. https://doi.org/10.1016/j.lfs.2020.117902

14. Mouffak S, Shubbar Q, Saleh E, El-Awady R (2021) Recent advances in management of COVID-19: a review. Biomed Pharmacother 143:112107. https://doi.org/10.1016/j.biopha.2021. 112107

15. Wichniak A, Kania A, Sieminski M, Cubala WJ (2021) Melatonin as a potential adjuvant treatment for COVID-19 beyond sleep disorders. Int J Mol Sci. https://doi.org/10.3390/ijms2 2168623

16. Ramos E, Lopez-Munoz F, Gil-Martin E, Egea J, Alvarez-Merz I, Painuli S, Semwal P, Martins N, Hernandez-Guijo JM, Romero A (2021) The coronavirus disease 2019 (COVID-19): key emphasis on melatonin safety and therapeutic efficacy. Antioxidants (Basel). https://doi.org/10.3390/antiox10071152

17. Boga JA, Coto-Montes A, Rosales-Corral SA, Tan DX, Reiter RJ (2012) Beneficial actions of melatonin in the management of viral infections: a new use for this "molecular handyman"? Rev Med Virol 22(5):323-338. https://doi.org/10.1002/rmv.1714

18. Bahrampour Juybari K, Pourhanifeh MH, Hosseinzadeh A, Hemati K, Mehrzadi S (2020) Melatonin potentials against viral infections including COVID-19: Current evidence and new findings. Virus Res 287:198108. https://doi.org/10.1016/j.virusres. 2020.198108

19. Lien CH, Lee MD, Weng SL, Lin CH, Liu LY, Tai YL, Lei WT, Liu JM, Huang YN, Chi H, Chiu NC, Lin CY (2021) Repurposing colchicine in treating patients with COVID-19: a systematic review and meta-analysis. Life (Basel). https://doi.org/10.3390/ life 11080864

20. Ward D, Gortz S, Ernst MT, Andersen NN, Kjaer SK, Hallas J, Christensen S, Christiansen CF, Israelsen SB, Benfield T, Pottegard A, Jess T (2021) The effect of immunosuppressants on the prognosis of SARS-CoV-2 infection. Eur Respir J. https:// doi.org/10.1183/13993003.00769-2021
21. Younis NK, Zareef RO, Fakhri G, Bitar F, Eid AH, Arabi M (2021) COVID-19: potential therapeutics for pediatric patients. Pharmacol Rep. https://doi.org/10.1007/s43440-021-00316-1

22. Ambrus C, Bakos E, Sarkadi B, Ozvegy-Laczka C, Telbisz A (2021) Interactions of anti-COVID-19 drug candidates with hepatic transporters may cause liver toxicity and affect pharmacokinetics. Sci Rep 11(1):17810. https://doi.org/10.1038/ s41598-021-97160-3

23. Malani M, Salunke P, Kulkarni S, Jain GK, Sheikh A, Kesharwani P (2021) Nirmal J (2021) Repurposing pharmaceutical excipients as an antiviral agent against SARS-CoV-2. J Biomater Sci Polym Ed 10(1080/09205063):1975020

24. Tiwari V, Kumar M, Tiwari A, Sahoo BM, Singh S, Kumar S, Saharan R (2021) Current trends in diagnosis and treatment strategies of COVID-19 infection. Environ Sci Pollut Res Int. https:// doi.org/10.1007/s11356-021-16715-z

25. Srivastava K, Singh MK (2021) Drug repurposing in COVID-19: a review with past, present and future. Metabol Open. https://doi. org/10.1016/j.metop.2021.100121

26. Elrashdy F, Tambuwala MM, Hassan SS, Adadi P, Seyran M, Abd El-Aziz TM, Rezaei N, Lal A, Aljabali AAA, Kandimalla R, Bazan NG, Azad GK, Sherchan SP, Choudhury PP, SerranoAroca A, Takayama K, Chauhan G, Pizzol D, Barh D, Panda PK, Mishra YK, Palu G, Lundstrom K, Redwan EM, Uversky VN (2021) Autoimmunity roots of the thrombotic events after COVID-19 vaccination. Autoimmun Rev. https://doi.org/10. 1016/j.autrev.2021.102941

27. Hasnie AA, Hasnie UA, Patel N, Aziz MU, Xie M, Lloyd SG, Prabhu SD (2021) Perimyocarditis following first dose of the mRNA-1273 SARS-CoV-2 (Moderna) vaccine in a healthy young male: a case report. BMC Cardiovasc Disord 21(1):375. https://doi.org/10.1186/s12872-021-02183-3

28. Patel YR, Louis DW, Atalay M, Agarwal S, Shah NR (2021) Cardiovascular magnetic resonance findings in young adult patients with acute myocarditis following mRNA COVID-19 vaccination: a case series. J Cardiovasc Magn Reson 23(1):101. https://doi. org/10.1186/s12968-021-00795-4

29. Al-Zyoud W, Haddad H (2021) Dynamics prediction of emerging notable spike protein mutations in SARS-CoV-2 implies a need for updated vaccines. Biochimie 191:91-103. https://doi.org/10. 1016/j.biochi.2021.08.011

30. Baj A, Novazzi F, Genoni A, Ferrante FD, Taborelli S, Pini B, Partenope M, Valli M, Gasperina DD, Capuano R, Prestia M, Spezia PG, Azzi L, Focosi D, Maggi F (2021) Symptomatic SARS-CoV-2 infections after full schedule BNT162b2 vaccination in seropositive healthcare workers: a case series from a single institution. Emerg Microbes Infect 10(1):1254-1256. https:// doi.org/10.1080/22221751.2021.1942230

31. Srinivasan V, Mohamed M, Kato H (2012) Melatonin in bacterial and viral infections with focus on sepsis: a review. Recent Pat Endocr Metab Immune Drug Discov 6(1):30-39. https://doi.org/ 10.2174/187221412799015317

32. Martin Gimenez VM, de Las HN, Ferder L, Lahera V, Reiter RJ, Manucha W (2021) Potential Effects of Melatonin and Micronutrients on Mitochondrial Dysfunction during a Cytokine Storm Typical of Oxidative/Inflammatory Diseases. Diseases. https:// doi.org/10.3390/diseases 9020030

33. Peschechera E, Veronesi PA (2020) Injectable melatonin: an anticancer and anti-viral treatment option. Melatonin Res 3(1):7780. https://doi.org/10.32794/mr11250049

34. Tan DX, Korkmaz A, Reiter RJ, Manchester LC (2014) Ebola virus disease: potential use of melatonin as a treatment. J Pineal Res 57(4):381-384. https://doi.org/10.1111/jpi.12186

35. Reiter RJ, Ma Q, Sharma R (2020) Treatment of ebola and other infectious diseases: melatonin "goes viral." Melatonin Res 3(1):43-57. https://doi.org/10.32794/mr11250047 
36. Artigas L, Coma M, Matos-Filipe P, Aguirre-Plans J, Farres J, Valls R, Fernandez-Fuentes N, de la Haba-Rodriguez J, Olvera A, Barbera J, Morales R, Oliva B, Mas JM (2020) In-silico drug repurposing study predicts the combination of pirfenidone and melatonin as a promising candidate therapy to reduce SARS$\mathrm{CoV}-2$ infection progression and respiratory distress caused by cytokine storm. PLoS ONE 15(10):e0240149. https://doi.org/10. 1371/journal.pone.0240149

37. Feitosa EL, Junior F, Nery Neto JAO, Matos LFL, Moura MHS, Rosales TO, De Freitas GBL (2020) COVID-19: Rational discovery of the therapeutic potential of Melatonin as a SARS-CoV-2 main Protease Inhibitor. Int J Med Sci 17(14):2133-2146. https:// doi.org/10.7150/ijms.48053

38. Chavarria AP, Vazquez RRV, Cherit JGD, Bello HH, Suastegui HC, Moreno-Castaneda L, Alanis Estrada G, Hernandez F, Gonzalez-Marcos O, Saucedo-Orozco H, Manzano-Pech L, MarquezVelasco R, Guarner-Lans V, Perez-Torres I, Soto ME (2021) Antioxidants and pentoxifylline as coadjuvant measures to standard therapy to improve prognosis of patients with pneumonia by COVID-19. Comput Struct Biotechnol J 19:1379-1390. https:// doi.org/10.1016/j.csbj.2021.02.009

39. Tekbas OF, Ogur R, Korkmaz A, Kilic A, Reiter RJ (2008) Melatonin as an antibiotic: new insights into the actions of this ubiquitous molecule. J Pineal Res 44(2):222-226. https://doi.org/10. 1111/j.1600-079X.2007.00516.X

40. He F, Wu X, Zhang Q, Li Y, Ye Y, Li P, Chen S, Peng Y, Hardeland R, Xia Y (2021) Bacteriostatic potential of melatonin: therapeutic standing and mechanistic insights. Front Immunol 12:683879. https://doi.org/10.3389/fimmu.2021.683879

41. Gitto E, Karbownik M, Reiter RJ, Tan DX, Cuzzocrea S, Chiurazzi P, Cordaro S, Corona G, Trimarchi G, Barberi I (2001) Effects of melatonin treatment in septic newborns. Pediatr Res 50(6):756-760. https://doi.org/10.1203/00006450-20011 2000-00021

42. D'Angelo G, Marseglia L, Reiter RJ, Buonocore G, Gitto E (2017) Melatonin and neonatal sepsis: a promising antioxidant adjuvant agent. Am J Perinatol 34(14):1382-1388. https://doi. org/10.1055/s-0037-1604244

43. D'Angelo G, Impellizzeri P, Marseglia L, Montalto AS, Russo T, Salamone I, Falsaperla R, Corsello G, Romeo C, Gitto E (2018) Current status of laboratory and imaging diagnosis of neonatal necrotizing enterocolitis. Ital J Pediatr 44(1):84. https://doi.org/ 10.1186/s13052-018-0528-3

44. Li G, Lv D, Yao Y, Wu H, Wang J, Deng S, Song Y, Guan S, Wang L, Ma W, Yang H, Yan L, Zhang J, Ji P, Zhang L, Lian Z, Liu G (2021) Overexpression of ASMT likely enhances the resistance of transgenic sheep to brucellosis by influencing immune-related signaling pathways and gut microbiota. FASEB J 35(9):e21783. https://doi.org/10.1096/fj.202100651R

45. Snider JM, You JK, Wang X, Snider AJ, Hallmark B, Zec MM, Seeds MC, Sergeant S, Johnstone L, Wang Q, Sprissler R, Carr TF, Lutrick K, Parthasarathy S, Bime C, Zhang HH, Luberto C, Kew RR, Hannun YA, Guerra S, McCall CE, Yao G, Del Poeta M, Chilton FH (2021) Group IIA secreted phospholipase A2 is associated with the pathobiology leading to COVID-19 mortality. J Clin Invest. https://doi.org/10.1172/JCI149236

46. van Hensbergen VP, Wu Y, van Sorge NM, Touqui L (2020) Type IIA Secreted Phospholipase A2 in Host Defense against Bacterial Infections. Trends Immunol 41(4):313-326. https://doi.org/10. 1016/j.it.2020.02.003

47. Yavuz T, Kaya D, Behcet M, Ozturk E, Yavuz O (2007) Effects of melatonin on Candida sepsis in an experimental rat model. Adv Ther 24(1):91-100. https://doi.org/10.1007/BF02849996

48. Prauchner CA (2017) Oxidative stress in sepsis: pathophysiological implications justifying antioxidant co-therapy. Burns 43(3):471-485. https://doi.org/10.1016/j.burns.2016.09.023
49. Natesan V (2018) Adrenergic blockade inhibits bacterial quorum sensing and reverses Warburg effect in septic shock. Br J Anaesth 120(2):412-413. https://doi.org/10.1016/j.bja.2017.12.010

50. Zhang D, Tang Z, Huang H, Zhou G, Cui C, Weng Y, Liu W, Kim S, Lee S, Perez-Neut M, Ding J, Czyz D, Hu R, Ye Z, He M, Zheng YG, Shuman HA, Dai L, Ren B, Roeder RG, Becker L, Zhao Y (2019) Metabolic regulation of gene expression by histone lactylation. Nature 574(7779):575-580. https://doi.org/ 10.1038/s41586-019-1678-1

51. de Jong TV, Guryev V, Moshkin YM (2021) Estimates of gene ensemble noise highlight critical pathways and predict disease severity in H1N1, COVID-19 and mortality in sepsis patients. Sci Rep 11(1):10793. https://doi.org/10.1038/s41598-021-90192-9

52. Luo Y, Li L, Chen X, Gou H, Yan K, Xu Y (2021) Effects of lactate in immunosuppression and inflammation: progress and prospects. Int Rev Immunol. https://doi.org/10.1080/08830185. 2021.1974856

53. Xia Y, Chen S, Zeng S, Zhao Y, Zhu C, Deng B, Zhu G, Yin Y, Wang W, Hardeland R, Ren W (2019) Melatonin in macrophage biology: current understanding and future perspectives. J Pineal Res 66(2):e12547. https://doi.org/10.1111/jpi. 12547

54. Schmoch T, Uhle F, Siegler BH, Fleming T, Morgenstern J, Nawroth PP, Weigand MA, Brenner T (2017) The glyoxalase system and methylglyoxal-derived carbonyl stress in sepsis: glycotoxic aspects of sepsis pathophysiology. Int J Mol Sci. https://doi.org/ 10.3390/ijms18030657

55. Tian M, Liu W, Li X, Zhao P, Shereen MA, Zhu C, Huang S, Liu S, Yu X, Yue M, Pan P, Wang W, Li Y, Chen X, Wu K, Luo Z, Zhang Q, Wu J (2021) HIF-1alpha promotes SARS-CoV-2 infection and aggravates inflammatory responses to COVID-19. Signal Transduct Target Ther 6(1):308. https://doi.org/10.1038/ s41392-021-00726-w

56. Merad M, Martin JC (2020) Pathological inflammation in patients with COVID-19: a key role for monocytes and macrophages. Nat Rev Immunol 20(6):355-362. https://doi.org/10. 1038/s41577-020-0331-4

57. Reiter RJ, Sharma R, Ma Q, Rosales-Corral S, Acuna-Castroviejo D, Escames G (2019) Inhibition of mitochondrial pyruvate dehydrogenase kinase: a proposed mechanism by which melatonin causes cancer cells to overcome cytosolic glycolysis, reduce tumor biomass and reverse insensitivity to chemotherapy. Melatonin Res 2(3):105-119. https://doi.org/10.32794/mr11250033

58. Reiter RJ, Sharma R, Rosales-Corral S (2021) Anti-warburg effect of melatonin: a proposed mechanism to explain its inhibition of multiple diseases. Int J Mol Sci. https://doi.org/10.3390/ ijms22020764

59. Peng T, Du SY, Son M, Diamond B (2021) HIF-1alpha is a negative regulator of interferon regulatory factors: implications for interferon production by hypoxic monocytes. Proc Natl Acad Sci USA. https://doi.org/10.1073/pnas.2106017118

60. Al-Gburi S, Beissert S, Gunther C (2021) Molecular mechanisms of vaculopathy and coagulopathy in COVID-19. Biol Chem. https://doi.org/10.1515/hsz-2021 $=0245$

61. Mansouri MA, Kee F, Garcia L, Bradley DT (2021) Role of systems science in preventing and controlling emerging infectious diseases: protocol for a scoping review. BMJ Open 11(6):e046057. https://doi.org/10.1136/bmjopen-2020-046057

62. Zhu B, Wu Y, Huang S, Zhang R, Son YM, Li C, Cheon IS, Gao X, Wang M, Chen Y, Zhou X, Nguyen Q, Phan AT, Behl S, Taketo MM, Mack M, Shapiro VS, Zeng H, Ebihara H, Mullon JJ, Edell ES, Reisenauer JS, Demirel N, Kern RM, Chakraborty R, Cui W, Kaplan MH, Zhou X, Goldrath AW, Sun J (2021) Uncoupling of macrophage inflammation from self-renewal modulates host recovery from respiratory viral infection. Immunity 
54(6):1200-1218e1209. https://doi.org/10.1016/j.immuni.2021. 04.001

63. Noroozneezhad AH, Mansouri K (2021) Endothelial cell dysfunction, coagulation, and angiogenesis in coronavirus disease 2019 (COVID-19). Microvasc Res 137:104188. https://doi.org/ 10.1016/j.mvr.2021.104188

64. Codo AC, Davanzo GG, Monteiro LB, de Souza GF, Muraro SP, Virgilio-da-Silva JV, Prodonoff JS, Carregari VC, de Biagi Junior CAO, Crunfli F, Jimenez Restrepo JL, Vendramini PH, Reis-de-Oliveira G, Bispo Dos Santos K, Toledo-Teixeira DA, Parise PL, Martini MC, Marques RE, Carmo HR, Borin A, Coimbra LD, Boldrini VO, Brunetti NS, Vieira AS, Mansour E, Ulaf RG, Bernardes AF, Nunes TA, Ribeiro LC, Palma AC, Agrela MV, Moretti ML, Sposito AC, Pereira FB, Velloso LA, Vinolo MAR, Damasio A, Proenca-Modena JL, Carvalho RF, Mori MA, Martins-de-Souza D, Nakaya HI, Farias AS, MoraesVieira PM (2020) Elevated Glucose Levels Favor SARS-CoV-2 Infection and Monocyte Response through a HIF-1alpha/Glycolysis-Dependent Axis. Cell Metab 32(3):437-446e435. https:// doi.org/10.1016/j.cmet.2020.07.007

65. Zonta YR, Martinez M, Camargo IC, Domeniconi RF, Lupi Junior LA, Pinheiro PF, Reiter RJ, Martinez FE, Chuffa LG (2017) Melatonin Reduces Angiogenesis in Serous Papillary Ovarian Carcinoma of Ethanol-Preferring Rats. Int J Mol Sci. https://doi.org/10.3390/ijms18040763

66. Maroufi NF, Amiri M, Dizaji BF, Vahedian V, Akbarzadeh M, Roshanravan N, Haiaty S, Nouri M, Rashidi MR (2020) Inhibitory effect of melatonin on hypoxia-induced vasculogenic mimicry via suppressing epithelial-mesenchymal transition (EMT) in breast cancer stem cells. Eur J Pharmacol 881:173282. https://doi.org/10.1016/j.ejphar.2020.173282

67. Yin W, Liu Y, Liu X, Ma X, Sun B, Yu Z (2021) Metformin inhibits epithelial-mesenchymal transition of oral squamous cell carcinoma via the mTOR/HIF-1alpha/PKM2/STAT3 pathway. Oncol Lett 21(1):31. https://doi.org/10.3892/ol.2020. 12292

68. Vriend J, Reiter RJ (2016) Melatonin and the von Hippel-Lindau/ HIF-1 oxygen sensing mechanism: a review. Biochim Biophys Acta 1865 2:176-183. https://doi.org/10.1016/j.bbcan.2016.02. 004

69. He M, Zhou C, Lu Y, Mao L, Xi Y, Mei X, Wang X, Zhang L, Yu Z, Zhou Z (2020) Melatonin antagonizes nickel-induced aerobic glycolysis by blocking ROS-mediated HIF-1alpha/miR210/ISCU axis activation. Oxid Med Cell Longev 2020:5406284. https:// doi.org/10.1155/2020/5406284

70. Costa JH, Mohanapriya G, Bharadwaj R, Noceda C, Thiers KLL, Aziz S, Srivastava S, Oliveira M, Gupta KJ, Kumari A, Sircar D, Kumar SR, Achra A, Sathishkumar R, Adholeya A, ArnholdtSchmitt B (2021) ROS/RNS Balancing, Aerobic Fermentation Regulation and Cell Cycle Control-a Complex Early Trait ('CoV-MAC-TED') for Combating SARS-CoV-2-Induced Cell Reprogramming. Front Immunol 12:673692. https://doi.org/10. 3389/fimmu.2021.673692

71. Martorina WJ, Tavares A (2021) Possible role of exogenous melatonin in preventing more serious COVID-19 infection in patients with type 2 diabetes mellitus. Rev Assoc Med Bras (1992) 67(Suppl 1):18-21. https://doi.org/10.1590/1806-9282. 67.Supp11.20200968

72. Hosseini A, Esmaeili Gouvarchin Ghaleh H, Aghamollaei H, Fasihi Ramandi M, Alishiri G, Shahriary A, Hassanpour K, Tat M, Farnoosh G (2021) Evaluation of Th1 and Th2 mediated cellular and humoral immunity in patients with COVID-19 following the use of melatonin as an adjunctive treatment. Eur J Pharmacol 904:174193. https://doi.org/10.1016/j.ejphar.2021. 174193
73. Letsiou E, Htwe YM, Dudek SM (2021) Secretory Phospholipase A2 Enzymes in Acute Lung Injury. Cell Biochem Biophys. https://doi.org/10.1007/s12013-021-01003-x

74. Lee LP, Tan KY, Tan CH (2021) Snake venom proteomics and antivenomics of two Sundaic lance-headed pit vipers: Trimeresurus wiroti (Malaysia) and Trimeresurus puniceus (Indonesia). Comp Biochem Physiol Part D Genomics Proteomics 40:100875. https://doi.org/10.1016/j.cbd.2021.100875

75. Zhao HY, Sun Y, Du Y, Li JQ, Lv JG, Qu YF, Lin LH, Lin CX, Ji X, Gao JF (2021) Venom of the annulated sea snake Hydrophis cyanocinctus: a biochemically simple but genetically complex weapon. Toxins (Basel). https://doi.org/10.3390/toxins 13080548

76. Khan H, Gupta A, Singh TG, Kaur A (2021) Mechanistic insight on the role of leukotriene receptors in ischemic-reperfusion injury. Pharmacol Rep 73(5):1240-1254. https://doi.org/10.1007/ s43440-021-00258-8

77. Kulkarni A, Nadler JL, Mirmira R, Casimiuro I (2021) Regulation of tissue inflammation by 12-lipoxygenase. Biomolcules 11(5):717. https://doi.org/10.3390/biom 11050717

78. Trostchansky A, Wood I, Rubbo H (2021) Regulation of arachidonic acid oxidation and metabolism by lipid electrophiles. Prostaglandins Other Lipid Mediat 152:106482. https://doi.org/ 10.1016/j.prostaglandins.2020.106482

79. Appiah MG, Park EJ, Akama Y, Nakamori Y, Kawamoto E, Gaowa A, Shimaoka M (2021) Cellular and exosomal regulations of sepsis-induced metabolic alterations. Int J Mol Sci. https://doi. org/10.3390/ijms22158295

80. Anderson G, Carbone A, Mazzoccoli G (2020) Aryl Hydrocarbon Receptor Role in Co-Ordinating SARS-CoV-2 Entry and Symptomatology: Linking Cytotoxicity Changes in COVID-19 and Cancers; Modulation by Racial Discrimination Stress. Biology (Basel). https://doi.org/10.3390/biology9090249

81. Bar-Or D, Carrick M, Tanner A 2nd, Lieser MJ, Rael LT, Brody E (2018) Overcoming the Warburg Effect: Is it the key to survival in sepsis? J Crit Care 43:197-201. https://doi.org/10.1016/j.jcrc. 2017.09.012

82. Chen X, Hao B, Li D, Reiter RJ, Bai Y, Abay B, Chen G, Lin S, Zheng T, Ren Y, Xu X, Li M, Fan L (2021) Melatonin inhibits lung cancer development by reversing the Warburg effect via stimulating the SIRT3/PDH axis. J Pineal Res. https://doi.org/ 10.1111/jpi.12755

83. Li M, Hao B, Zhang M, Reiter RJ, Lin S, Zheng T, Chen X, Ren Y, Yue L, Abay B, Chen G, Xu X, Shi Y, Fan L (2021) Melatonin enhances radiofrequency-induced NK antitumor immunity, causing cancer metabolism reprogramming and inhibition of multiple pulmonary tumor development. Signal Transduct Target Ther 6(1):330. https://doi.org/10.1038/s41392-021-00745-7

84. Tan TL, Goh YY (2017) The role of group IIA secretory phospholipase A2 (sPLA2- IIA) as a biomarker for the diagnosis of sepsis and bacterial infection in adults-A systematic review. PLoS ONE 12(7):e0180554. https://doi.org/10.1371/journal. pone. 0180554

85. Bickler PE (2020) Amplification of Snake Venom Toxicity by Endogenous Signaling Pathways. Toxins (Basel). https://doi.org/ 10.3390/toxins 12020068

86. de Araujo PL, de Almeida MES, Bretones ML, Cirillo MC, Curi R, Sampaio SC (2019) Crotoxin promotes macrophage reprogramming towards an antiangiogenic phenotype. Sci Rep 9(1):4281. https://doi.org/10.1038/s41598-019-40903-0

87. Katkar GD, Sundaram MS, Hemshekhar M, Sharma DR, Santhosh MS, Sunitha K, Rangappa KS, Girish KS, Kemparaju K (2014) Melatonin alleviates Echis carinatus venom-induced toxicities by modulating inflammatory mediators and oxidative stress. J Pineal Res 56(3):295-312. https://doi.org/10.1111/jpi. 12123 
88. Abdel Moneim AE, Ortiz F, Leonardo-Mendonca RC, VerganoVillodres R, Guerrero-Martinez JA, Lopez LC, Acuna-Castroviejo D, Escames G (2015) Protective effects of melatonin against oxidative damage induced by Egyptian cobra (Naja haje) crude venom in rats. Acta Trop 143:58-65. https://doi.org/10. 1016/j.actatropica.2014.12.007

89. Estaras M, Gonzalez-Portillo MR, Fernandez-Bermejo M, Mateos JM, Vara D, Blanco-Fernandez G, Lopez-Guerra D, Roncero V, Salido GM, Gonzalez A (2021) Melatonin Induces Apoptosis and Modulates Cyclin Expression and MAPK Phosphorylation in Pancreatic Stellate Cells Subjected to Hypoxia. Int J Mol Sci. https://doi.org/10.3390/ijms22115555

90. Marino A, Di Paola R, Crisafulli C, Mazzon E, Morabito R, Paterniti I, Galuppo M, Genovese T, La Spada G, Cuzzocrea S (2009) Protective effect of melatonin against the inflammatory response elicited by crude venom from isolated nematocysts of Pelagia noctiluca (Cnidaria, Scyphozoa). J Pineal Res 47(1):5669. https://doi.org/10.1111/j.1600-079X.2009.00688.x

91. Reiter RJ, Mayo JC, Tan DX, Sainz RM, Alatorre-Jimenez M, Qin L (2016) Melatonin as an antioxidant: under promises but over delivers. J Pineal Res 61(3):253-278. https://doi.org/10. $1111 /$ jpi.12360

92. Hardeland R (2019) Aging, Melatonin, and the Pro- and AntiInflammatory Networks. Int J Mol Sci. https://doi.org/10.3390/ ijms20051223

93. Perez-Gonzalez A, Castaneda-Arriaga R, Alvarez-Idaboy JR, Reiter RJ, Galano A (2019) Melatonin and its metabolites as chemical agents capable of directly repairing oxidized DNA. J Pineal Res 66(2):e12539. https://doi.org/10.1111/jpi.12539

94. Tan DX, Hardeland R (2020) Targeting Host Defense System and Rescuing Compromised Mitochondria to Increase Tolerance against Pathogens by Melatonin May Impact Outcome of Deadly Virus Infection Pertinent to COVID-19. Molecules. https://doi. org/10.3390/molecules25194410

95. Castillo RR, Quizon GRA, Juco MJM, Roman ADE, de Leon DG, Punzalan FER, R.B.L. G, Morales DD, Tan D-X, Reiter RJ (2020) Melatonin as adjuvant treatment for coronavirus disease 2019 pneumonia patients requiring hospitalization (MAC-19 PRO): a case series. Melatonin Res 3 (3):297-310. https://doi. org/10.32794/mr11250063

96. Farnoosh G, Akbariqomi M, Badri T, Bagheri M, Izadi M, Saeedi-Boroujeni A, Rezaie E, Ghaleh HEG, Aghamollaei H, Fasihi-Ramandi M, Hassanpour K, Alishiri G (2021) Efficacy of a Low Dose of Melatonin as an Adjunctive Therapy in Hospitalized Patients with COVID-19: A Randomized, Double-blind Clinical Trial. Arch Med Res. https://doi.org/10.1016/j.arcmed. 2021.06.006

97. Ellis LC (1996) Melatonin reduces mortality from Aleutian disease in mink (Mustela vison). J Pineal Res 21(4):214-217. https://doi.org/10.1111/j.1600-079x.1996.tb00288.x

98. Maestroni GJ (1999) Therapeutic potential of melatonin in immunodeficiency states, viral diseases, and cancer. Adv Exp Med Biol 467:217-226. https://doi.org/10.1007/978-1-4615-4709-9_ 28

99. Vielma JR, Bonilla E, Chacin-Bonilla L, Mora M, MedinaLeendertz S, Bravo Y (2014) Effects of melatonin on oxidative stress, and resistance to bacterial, parasitic, and viral infections: a review. Acta Trop 137:31-38. https://doi.org/10.1016/j.actat ropica.2014.04.021

100. Montiel M, Bonilla E, Valero N, Mosquera J, Espina LM, Quiroz Y, Alvarez-Mon M (2015) Melatonin decreases brain apoptosis, oxidative stress, and CD200 expression and increased survival rate in mice infected by Venezuelan equine encephalitis virus. Antivir Chem Chemother 24(3-4):99-108. https://doi.org/10. $1177 / 2040206616660851$
101. Morchang A, Malakar S, Poonudom K, Noisakran S, Yenchitsomanus PT, Limjindaporn T (2021) Melatonin Inhibits Dengue Virus Infection via the Sirtuin 1-Mediated Interferon Pathway. Viruses. https://doi.org/10.3390/v13040659

102. Zhai X, Wang N, Jiao H, Zhang J, Li C, Ren W, Reiter RJ, Su $S$ (2021) Melatonin and other indoles show antiviral activities against swine coronaviruses in vitro at pharmacological concentrations. J Pineal Res. https://doi.org/10.1111/jpi.12754

103. Hasan ZT, Atrakji D, Mehuaiden DAK (2021) The Effect of Melatonin on Thrombosis, Sepsis and Mortality Rate in COVID-19 Patients. Int J Infect Dis. https://doi.org/10.1016/j.ijid.2021.10.012

104. Mousavi SA, Heydari K, Mehravaran H, Saeedi M, AlizadehNavaei R, Hedayatizadeh-Omran A, Shamshirian A (2022) Melatonin effects on sleep quality and outcomes of COVID-19 patients: An open-label, randomized, controlled trial. J Med Virol 94(1):263-271. https://doi.org/10.1002/jmv.27312

105. Alizadeh Z, Keyhanian N, Ghaderkhani S, Dashti-Khavidaki S, Shokouhi Shoormasti R, Pourpak Z (2021) A Pilot Study on Controlling Coronavirus Disease 2019 (COVID-19) Inflammation Using Melatonin Supplement. Iran J Allergy Asthma Immunol 20(4):494-499

106. Sack RL, Lewy AJ, Erb DL, Vollmer WM, Singer CM (1986) Human melatonin production decreases with age. J Pineal Res 3(4):379-388. https://doi.org/10.1111/j.1600-079x.1986.tb007 $60 . \mathrm{x}$

107. Scholtens RM, van Munster BC, van Kempen MF, de Rooij SE (2016) Physiological melatonin levels in healthy older people: a systematic review. J Psychosom Res 86:20-27. https://doi.org/ 10.1016/j.jpsychores.2016.05.005

108. Oba S, Altinay M, Salkaya A, Turk HS (2021) Evaluation of the effect of clinical characteristics and intensive care treatment methods on the mortality of covid-19 patients aged 80 years and older. BMC Anesthesiol 21(1):291. https://doi.org/10.1186/ s12871-021-01511-6

109. Vaughan GM (1986) Human melatonin in physiologic and diseased states: neural control of the rhythm. J Neural Transm Suppl 21:199-215

110. Pandi-Perumal S, Cardinali D, Reiter RJ, Brown G (2020) Low melatonin as a contributor to SARS-CoV-2 disease. Melatonin Res 3(4):558-576. https://doi.org/10.32794/mr11250079

111. Nordlund JJ, Lerner AB (1977) The effects of oral melatonin on skin color and on the release of pituitary hormones. J Clin Endocrinol Metab 45(4):768-774. https://doi.org/10.1210/ jcem-45-4-768

112. Lu KH, Lu PW, Lu EW, Tang CH, Su SC, Lin CW, Yang SF (2021) The potential remedy of melatonin on osteoarthritis. J Pineal Res 71(3):e12762. https://doi.org/10.1111/jpi.12762

113. Jaworek AK, Szepietowski JC, Halubiec P, Wojas-Pelc A, Jaworek J (2021) Melatonin as an antioxidant and immunomodulator in atopic dermatitis-a new look on an old story: a review. Antioxidants. https://doi.org/10.3390/antiox10081179

114. Hardeland R (2021) Melatonin and Microglia. Int J Mol Sci. https://doi.org/10.3390/ijms22158296

115. Wongchitrat P, Shukla M, Sharma R, Govitrapong P, Reiter RJ (2021) Role of Melatonin on Virus-Induced Neuropathogenesis-A Concomitant Therapeutic Strategy to Understand SARSCoV-2 Infection. Antioxidants (Basel). https://doi.org/10.3390/ antiox 10010047

116. Baltatu OC, Amaral FG, Campos LA, Cipolla-Neto J (2017) Melatonin, mitochondria and hypertension. Cell Mol Life Sci 74(21):3955-3964. https://doi.org/10.1007/s00018-017-2613-y

117. Targhetta VP, Amaral MA, Camara NOS (2021) Through DNA sensors and hidden mitochondrial effects of SARS-CoV-2. J Venom Anim Toxins Incl Trop Dis 27:e20200183. https://doi. org/10.1590/1678-9199-JVATITD-2020-0183 
118. Alonazi B, Farghaly AM, Mostafa MA, Al-Watban JA, Zindani SA, Altaimi F, Fagiry MA, Mahmoud MZ (2021) Brain MRI in SARS-CoV-2 pneumonia patients with newly developed neurological manifestations suggestive of brain involvement. Sci Rep 11(1):20476. https://doi.org/10.1038/s41598-021-00064-5

119. Ristic-Medic D, Petrovic S, Arsic A, Vucic V (2021) Liver disease and COVID-19: the link with oxidative stress, antioxidants and nutrition. World J Gastroenterol 27(34):5682-5699. https:// doi.org/10.3748/wjg.v27.i34.5682

120. Wang H, Wang Z, Cao W, Wu Q, Yuan Y, Zhang X (2021) Regulatory T cells in COVID-19. Aging Dis 12(7):1545-1553. https:// doi.org/10.14336/AD.2021.0709

121. Vaamonde-Garcia C, Lopez-Armada MJ (2019) Role of mitochondrial dysfunction on rheumatic diseases. Biochem Pharmacol 165:181-195. https://doi.org/10.1016/j.bcp.2019.03.008

122. Xu X, Lin JI, Bais AS, Reynolds MJ, Tan T, Gabriel GC, Kondos Z, Liu X, Shiva SS, Lo CW (2021) Mitochondrial respiration defects in single-ventricle congenital heart disease. Front Cardiovasc Med 8:734388. https://doi.org/10.3389/fcvm.2021.734388

123. Yang Q, Wang L, Liu J, Cao W, Pan Q, Li M (2021) Targeting the complex I and III of mitochondrial electron transport chain as a potentially viable option in liver cancer management. Cell Death Discovery 7(1):293. https://doi.org/10.1038/s41420-021-00675-x

124. Chen C, Yang C, Wang J, Huang X, Yu H, Li S, Li S, Zhang Z, Liu J, Yang X, Liu GP (2021) Melatonin ameliorates cognitive deficits through improving mitophagy in a mouse model of Alzheimer's disease. J Pineal Res. https://doi.org/10.1111/jpi.12774

125. Rochette L, Ghibu S (2021) Mechanics insights of alpha-lipoic acid against cardiovascular diseases during COVID-19 infection. Int J Mol Sci. https://doi.org/10.3390/ijms22157979

126. Swain O, Romano SK, Miryala R, Tsai J, Parikh V, Umanah GKE (2021) SARS-CoV-2 neuronal invasion and complications: potential mechanisms and therapeutic approaches. J Neurosci 41(25):5338-5349. https://doi.org/10.1523/JNEUROSCI.318820.2021

127. Science M, Bolotin S, Silverman M, Nadarajah J, Maguire B, Parekh RS, McGeer A, Schwartz KL, Alexander L, Allen U, Ariyarajah A, Castellani L, Cohn RD, Downing M, Katz K, Kazmi K, Leis JA, Liu D, Pernica JM, Schneiderman JE, Sumaida M, Campigotto A (2021) SARS-CoV-2 antibodies in Ontario health care workers during and after the first wave of the pandemic: a cohort study. CMAJ Open 9(4):E929-E939. https://doi.org/10. 9778/cmajo.20210044

128. Xia MZ, Liang YL, Wang H, Chen X, Huang YY, Zhang ZH, Chen YH, Zhang C, Zhao M, Xu DX, Song LH (2012) Melatonin modulates TLR4-mediated inflammatory genes through MyD88and TRIF-dependent signaling pathways in lipopolysaccharidestimulated RAW2647 cells. J Pineal Res 53(4):325-334. https:// doi.org/10.1111/j.1600-079X.2012.01002.x

129. Reiter RJ, Sharma R, Ma Q, Rorsales-Corral S, de Almeida Chuffa LG (2020) Melatonin inhibits Warburg-dependent cancer by redirecting glucose oxidation to the mitochondria: a mechanistic hypothesis. Cell Mol Life Sci 77(13):2527-2542. https:// doi.org/10.1007/s00018-019-03438-1

130. Reiter RJ, Ma Q, Sharma R (2020) Melatonin in mitochondria: mitigating clear and present dangers. Physiology (Bethesda) 35(2):86-95. https://doi.org/10.1152/physiol.00034.2019

131. Suofu Y, Li W, Jean-Alphonse FG, Jia J, Khattar NK, Li J, Baranov SV, Leronni D, Mihalik AC, He Y, Cecon E, Wehbi VL, Kim J, Heath BE, Baranova OV, Wang X, Gable MJ, Kretz ES, Di Benedetto G, Lezon TR, Ferrando LM, Larkin TM, Sullivan M, Yablonska S, Wang J, Minnigh MB, Guillaumet G, Suzenet F, Richardson RM, Poloyac SM, Stolz DB, Jockers R, Witt-Enderby PA, Carlisle DL, Vilardaga JP, Friedlander RM (2017) Dual role of mitochondria in producing melatonin and driving GPCR signaling to block cytochrome $\mathrm{c}$ release. Proc Natl
Acad Sci USA 114(38):E7997-E8006. https://doi.org/10.1073/ pnas. 1705768114

132. Castle RD, Williams MA, Bushell WC, Rindfleisch JA, Peterson CT, Marzolf J, Brouwer K, Mills PJ (2021) Implications for systemic approaches to COVID-19: effect sizes of remdesivir, tocilizumab, melatonin, vitamin D3, and meditation. J Inflamm Res 14:4859-4876. https://doi.org/10.2147/JIR.S323356

133. Takahashi T, Luzum JA, Nicol MR, Jacobson PA (2020) Pharmacogenomics of COVID-19 therapies. NPJ Genom Med 5:35. https://doi.org/10.1038/s41525-020-00143-y

134. Yang CJ, Wei YJ, Chang HL, Chang PY, Tsai CC, Chen YH, Hsueh PR (2021) Remdesivir use in the coronavirus disease 2019 pandemic: a mini-review. J Microbiol Immunol Infect 54(1):2736. https://doi.org/10.1016/j.jmii.2020.09.002

135. Anderson TS, Good CB, Gellad WF (2015) Prevalence and compensation of academic leaders, professors, and trustees on publicly traded US healthcare company boards of directors: cross sectional study. BMJ 351:h4826. https://doi.org/10.1136/bmj. h4826

136. Becker C (2020) Relationships between academic medicine leaders and industry-time for another look? JAMA 324(18):18331834. https://doi.org/10.1001/jama.2020.21021

137. Dyer O (2021) Covid-19: "Shkreli Awards" go to pandemic's top profiteers. BMJ 372:n16. https://doi.org/10.1136/bmj.n16

138. Kleszczynski K, Slominski AT, Steinbrink K, Reiter RJ (2020) Clinical Trials for Use of Melatonin to Fight against COVID-19 Are Urgently Needed. Nutrients. https://doi.org/10.3390/nu120 92561

139. Shavit R, Maoz-Segal R, Iancovici-Kidon M, Offengenden I, Haj Yahia S, Machnes Maayan D, Lifshitz-Tunitsky Y, Niznik S, Frizinsky S, Deutch M, Elbaz E, Genaim H, Rahav G, Levy I, Belkin A, Regev-Yochay G, Afek A, Agmon-Levin N (2021) Prevalence of Allergic Reactions After Pfizer-BioNTech COVID19 Vaccination Among Adults With High Allergy Risk. JAMA Netw Open 4(8):e2122255. https://doi.org/10.1001/jamanetwor kopen.2021.22255

140. Warren CM, Snow TT, Lee AS, Shah MM, Heider A, Blomkalns A, Betts B, Buzzanco AS, Gonzalez J, Chinthrajah RS, Do E, Chang I, Dunham D, Lee G, O'Hara R, Park H, Shamji MH, Schilling L, Sindher SB, Sisodiya D, Smith E, Tsai M, Galli SJ, Akdis C, Nadeau KC (2021) Assessment of Allergic and Anaphylactic Reactions to mRNA COVID-19 Vaccines With Confirmatory Testing in a US Regional Health System. JAMA Netw Open 4(9):e2125524. https://doi.org/10.1001/jamanetwor kopen.2021.25524

141. Bardenheier BH, Gravenstein S, Blackman C, Gutman R, Sarkar IN, Feifer RA, White EM, McConeghy K, Nanda A, Bosco E, Mor V (2021) Adverse Events Following One Dose of mRNA COVID-19 Vaccination Among US Nursing Home Residents With and Without a Previous SARS-CoV-2 Infection. J Am Med Dir Assoc. https://doi.org/10.1016/j.jamda.2021.08.024

142. Lee RU, Glickman GL (2021) Sleep, Circadian Health and Melatonin for Mitigating COVID-19 and Optimizing Vaccine Efficacy. Front Neurosci 15:711605. https://doi.org/10.3389/fnins.2021. 711605

143. Gurunathan S, Kang M-H, Choi Y, Reiter RJ, Kim J-H (2021) Melatonin: a potential therapeutic agent against COVID-19. Melatonin Res 4(1):30-69. https://doi.org/10.32794/mr11250081

144. Cardinali DP, Brown GM, Pandi-Perumal SR An urgent proposal for the immediate use of melatonin as an adjuvant to anti- SARSCoV-2 vaccination. Melatonin Res 4 (1):206-212. doi:https://doi. org/10.32794/mr11250091.

Publisher's Note Springer Nature remains neutral with regard to jurisdictional claims in published maps and institutional affiliations. 